\title{
HUBUNGAN ANTARA KONSEP DIRI DENGAN KEEFEKTIVAN KOMUNIKASI ANTARPRIBADI \\ Studi pada Anggota AIESEC Local Committee (LC) Bandung
}

\author{
Tine Agustin Wulandari \\ Universitas Komputer Indonesia
}

\begin{abstract}
ABSTRAK
Konsep diri merupakan faktor yang sangat menentukan dalam komunikasi antarpribadi, karena setiap orang bertingkah laku sedapat mungkin sesuai dengan konsep dirinya. Setiap manusia memiliki konsep diri, maka hal tersebut juga berlaku pada anggota AIESEC Local Commitee (LC) Bandung. Metode korelasional digunakan untuk mengetahui sejauhmana hubungan antara konsep diri anggota AIESEC dengan keefektifan komunikasi antarpribadi.Populasi penelitian ini adalah anggota AIESEC Local Committee (LC) Bandung. Sampel penelitian diperoleh dengan menggunakan teknik sampling acak (random). Hasil penelitian menunjukkan hubungan antara konsep diri anggota AIESEC dengan keefektifan komunikasi antarpribadi adalah sangat kuat dengan koefisien korelasi 0,839 . Nilai korelasi positif menunjukkan hubungan yang searah. Uji hipotesis menghasilkan penolakan $\mathrm{H}_{0}$ sehingga terdapat hubungan yang signifikan diantara keduanya.
\end{abstract}

Kata-kata Kunci: Konsep diri, keefektifan komunikasi antarpribadi, AIESEC

\section{RELATIONSHIP BETWEEN SELF-CONCEPT WITH INTERPERSONAL COMMUNICATION EFFECTIVENESS Study of AIESEC Members Local Committee (LC) Bandung}

\section{ABSTRACT}

Self-concept is a crucial factor in interpersonal communication as everyone behaves as far as they could according to their self-concept. Every human being has self-concept, which applies to member of AIESEC (Association Internationale dex Etudiants en Sciencex Economiques et Commercialcs) Local Committee (LC) Bandung. Corelational method used todetermined the extent of the relationship between self-concept of AIESEC members with interpersonal communication effectiveness. The population of this research is member of AIESEC Local Committee (LC) Bandung. Random sampling technique used to obtained research sample. Result of this research shows that relationship betweenself-concept of AIESEC members with interpersonal communication effectiveness was very strong with correlation coefficient of 0,839 . Positive correlation value indicates one direction relationship. Hypothesis test result shows $H_{0}$ rejection, which indicates that there is a significant relationship between these two variables.

Keywords: Self concept, interpersonal communication, effectiveness, AIESEC

Korespondensi: Tine Agustin Wulandari, M.I.Kom. Universitas Komputer Indonesia, Jl. Dipati Ukur 112116 Bandung 40132. Email: neu.wulandari@gmail.com 


\section{PENDAHULUAN}

Komunikasi bergantung pada kemampuan manusia untuk memahami satu sama lain. Walaupun komunikasi yang dilakukan dapat bermakna ambigu, satu tujuan utama manusia berkomunikasi adalah pemahaman. Sudah disadari bahwa komunikasi bukan obat mujarab bagi semua permasalahan sosial. Tetapi kegagalan dalam komunikasi dapat menimbulkan kerugian yang besar bagi pihakpihak yang terlibat. Artinya, komunikasi merupakan keterampilan yang sangat penting dalam kehidupan manusia. Selain itu karena komunikasi dapat terjadi pada setiap gerak langkah manusia. Kehidupan manusia tidak dapat dilepaskan dari aktivitas komunikasi, sehingga komunikasi merupakan bagian integral dari sistem dan tatanan kehidupan sosial manusia.

Shelley D. Lane (2008: 70) mengungkapkan bahwa komunikasi yang dilakukan menentukan konsep diri seseorang, tetap iselain itu konsep diri juga menentukan bagaimana orang tersebut berkomunikasi dengan orang lain. Sehubungan dengan definisi tersebut, Jalaluddin Rakhmat (2011: 98) menuliskan bahwa konsep diri adalah pandangan dan perasaan kita tentang diri kita. Jadi, konsep diri meliputi apa yang seseorang pikirkan dan apa yang seseorang rasakan tentang dirinya.

Konsep diri merupakan bagian yang penting dari kepribadian seseorang yaitu sebagai penentu bagaimana seseorang bersikap dan bertingkah laku. Jika manusia memandang dirinya tidak mampu, tidak berdaya dan halhal negatif lainnya, ini akan mempengaruhi dia dalam berusaha. Konsep diri menjadi sangat mempengaruhi kepribadian seseorang, dengan konsep diri yang dimiliki, setiap perbuatan atau tingkah laku seseorang didasarkan pada konsep yang dibentuknya untuk tampil dan bertingkah laku sesuai dengan konsep dirinya.

James F. Calhoun dan Joan Ross Acocella (1995: 67) mengatakan, konsep diri memiliki tiga dimensi, yaitu pengetahuan, pengharapan, dan penilaian tentang diri sendiri.Dimensi pertama dari konsep diri adalah apa yang seseorang ketahui tentang dirinya sendiri. Dalam benak seseorang, ada satu daftar julukan yang menggambarkan dirinya: usia, jenis kelamin, kebangsaan, suku, pekerjaan, dan lain sebagainya (Calhoun dan Acocella, 1995: 67).
Dimensi kedua adalah harapan. Pada saat seseorang mempunyai satuset pandangan tentang siapa dirinya, orang tersebut juga mempunyai satu set pandangan lain yaitu tentang kemungkinan menjadi apa di masa mendatang (Rogers dalam Calhoun dan Acocella, 1995: 71). Pengharapan merupakan diri ideal. Diri ideal tersebut sangat berbeda untuk setiap individu. Apapun harapan atau tujuan yang dimiliki seseorang, akan membangkitkan kekuatan yang mendorongnya menuju masa depan dan memandu kegiatannya dalam perjalanan hidup. Selanjutnya setelah seseorang dapat mencapai tujuannya, akan muncul cita-cita lain.

Dimensi ketiga konsep diri adalah penilaian terhadap diri sendiri. Seorang individu berkedudukan sebagai penilai tentang dirinya setiap hari, mengukur apakah dirinya bertentangan dengan pengharapan bagi dirinya sendiri dan standar yang diterapkan bagi diri sendiri (Epstein dalam Calhoun dan Acocella, 1995: 71). Hasil pengukuran tersebut disebut dengan harga diri, yang pada dasarnya berarti seberapa besar seseorang menyukai dirinya sendiri. Semakin besar ketidaksesuaian antara gambaran tentang siapa dirinya dan gambaran tentang seharusnya menjadi apa atau dapat menjadi apa, akan semakin rendah rasa harga diri yang dimiliki (Rogers dalam Calhoun danAcocella, 1995: 71). Jadi, orang yang hidup sesuai dengan standar dan harapan-harapannya akan memiliki rasa harga diri tinggi. Hal lain yang perlu disadari mengenai konsep diri, menurut Jalaluddin Rakhmat (2011: 102), konsep diri merupakan faktor yang sangat menentukan dalam komunikasi antarpribadi, karena setiap orang bertingkah laku sedapat mungkin sesuai dengan konsep dirinya.

Sebagai bentuk perilaku yang lain, komunikasi antarpribadi dapat terjadi sangat efektif atau sebaliknya, sangat tidak efektif. Sedikit saja komunikasi antarpribadi yang gagal total atau berhasil total, tetapi ada komunikasi yang berlangsung lebih efektif dibandingkan yang lain.

Menurut Joseph A. DeVito (2011: 285), karakteristik keefektifan komunikasi antarpribadi dapat dilihat dari tiga sudut pandang, yaitu: sudut pandang humanistik, sudut pandang pragmatis, serta sudut pandang pergaulan sosial dan sudut pandang kesetaraan. Diantara ketiga sudut pandang tersebut, sudut pandang humanistik menekankan pada 
keterbukaan, empati, sikap mendukung, dan kualitas-kualitas lain yang menciptakan interaksi yang bermakna, jujur, dan memuaskan. Sudut pandang humanistik adakalanya dinamakan "ancangan lunak" dengan kualitas umum yang dapat dipertimbangkan: keterbukaan (openess), empati (empathy), sikap mendukung (supportiveness), sikap positif (positiveness), dan kesetaraan (equality).

Salah satu organisasi yang semestinya menyadari tentang konsep diri dan komunikasi antarpribadi para anggotanya adalah AIESEC. AIESEC merupakan sebuah organisasi yang berdiri pada tahun 1948 dengan nama Association Internationale dex Etudiants en Sciencex Economiques et Commercialcs (Bahasa Perancis) disingkat AIESEC. Saat ini, kepanjangan itu tidak lagi digunakan karena dirasa tak lagi relevan dengan konsentrasi AIESEC yang tidak hanya pada bidang ekonomi. Sehingga AIESEC tidak lagi merupakan akronim, melainkan sebuah brand yang digunakan secara luas.

AIESEC Indonesia telah menjadi platform bagi para pemuda di Indonesia untuk mengembangkan potensi kepemimpinan mereka melalui pengalaman kepemimpinan yang unik. Saat ini, AIESEC Indonesia terdapat di 14 kota dan 28 Perguruan Tinggi. Dewan kepemimpinan AIESEC mengalami perubahan setiap tahun, dari komite eksekutif lokal sampai ke tim kepemimpinan nasional.

Konsep diri anggota AIESEC menarik untuk diteliti karena seperti disebutkan dalam The AIESEC Way bahwa AIESEC merupakan organisasi global, yang bersifat non-politik, mandiri, tidak bertujuan untuk mencari keuntungan, dijalankan oleh mahasiswa ataupun mereka yang baru menyelesaikan pendidikan tinggi. Anggota AIESEC biasanya memiliki ketertarikan dengan isu-isu dunia, kepemimpinan, maupun manajemen. Selain itu, AIESEC tidak melakukan diskriminas berdasarkan ras, warna kulit, jenis kelamin, orientasi seksual, keyakinan, kepercayaan, kebangsaan, etnis, maupun asal-usul sosial. AIESEC juga menjadi jaringan pemuda yang berusaha untuk memberikan dampak kepada dunia melalui pengalaman dalam mengembangkan kepemimpinan, dengan memfasilitasi aktivitas kepemimpinan bagi pemuda melalui pelatihan berskala internasional maupun pengalaman menjadi sukarelawan selama lebih dari 65 tahun serta membangun lingkungan belajar global di 124 negara, termasuk Indonesia.

AIESEC memiliki sistem yang disebut AIESEC Experience (AIESEC XP) yang merupakan jalur karir yang dilewati seorang anggota AIESEC untuk mencapai pengembangan diri yang maksimal melalui AIESEC. Selama menjadi anggota AIESEC dan terlibat dalam semua tahapan AIESEC Experience, konsep diri anggota AIESEC akan menentukan komunikasi antarpribadi yang terjadi diantara anggota AIESEC Local Committee (LC) Bandung.

LC adalah sebutan untuk komisi lokal AIESEC yang membentuk dirinya di bawah badan universitas maupun secara independen berbasis sebuah kota. Bandung adalah salah satu kota yang menjadi LC dari AIESEC Indonesia. AIESEC LC Bandung terdiri dari enam universitas, yaitu Universitas Padjadjaran (Unpad), Institut Teknologi Bandung (ITB), Universitas Katolik Parahyangan (Unpar), Universitas Pendidikan Indonesia (UPI), Telkom University (Tel-U), serta Universitas Kristen Maranatha.

Berdasarkan uraian yang telah diungkapkan, maka peneliti merasa tertarik untuk mengetahui hubungan antara konsep diri anggota AIESEC LC Bandung dengan keefektifan komunikasi antarpribadi.

\section{METODE PENELITIAN}

Penelitian ini berusaha mengetahui konsep diri anggota sebuah organisasi yang menghasilkan komunikasi antarpribadi yang efektif, maka penelitian ini sejalan dengan paham kaum pos-positivis yakni filsafat deterministik yang menyatakan bahwa faktor kausatif sangat mungkin menentukan suatu hasil akhir (Creswell, 2012: 9). Metode penelitian yaitu jenis rancangan penelitian yang digunakan dalam penelitian ini adalah Metode Kuantitatif karena penelitian ini memiliki jenis data berupa angka-angka (Siregar, 2013: 8).

Penelitian ini bermaksud untuk menemukan generalisasi dari hubungan konsep diri anggota AIESEC LC Bandung dengan keefektifan komunikasi antarpribadi. Berdasarkan karakteristik tersebut maka metode penelitian yang tepat untuk digunakan adalah Penelitian Survei. Karena penelitian ini bermaksud mencari 
kausalitas diantara gejala pada masyarakat maka penelitian ini termasuk ke dalam jenis Penelitian Eksplanasi (Bungin, 2011: 46).

Skala pengukuran yang digunakan dalam penelitian ini adalah Skala Ordinal. Sedangkan instrumen penelitian berupa Angket menggunakan pernyataan dengan Skala Likert, karena skala ini dapat digunakan untuk mengukur sikap, pendapat, dan persepsi seseorang terhadap objek dan fenomena tertentu, yaitu konsep diri anggota AIESEC LC Bandung dengan keefektifan komunikasi antarpribadi. Dimana skala likert ini memiliki dua bentuk pernyataan yaitu pernyataan yang positif dan negatif (Siregar, 2013: 25). Berikut ini tabel operasionalisasi variabel:

Menurut Bungin (2011: 116), penelitian kuantitatif menggunakan Rancangan Sampel Probabilitas (Probability Sampling Design). Kategori sampel probabilitas yang digunakan dalam penelitian ini adalah sampling acak (random).

Langkah awal penetapan sampel dilakukan dengan menggunakan Rumus Slovin karena jumlah populasi diketahui dengan pasti dan populasi tidak terlalu besar (Siregar, 2013: 34). Dengan tingkat kesalahan ditetapkan di antara 5\% dan tingkat kepercayaan 95\% maka diperoleh jumlah sampel penelitian ini adalah 127 responden yang merupakan anggota AIESEC LC Bandung yang aktif.

Peneliti mengambil unit populasi dari atas ke bawah secara sistematis, kemudian mempersiapkan daftar rekapitulasi unit-unit populasi. Angka pertama diacak antara angka 2 sampai 5, yang terpilih adalah angka 2.Dengan demikian yang terpilih sebagai sampel adalah unit populasi yang berada pada urutan 4, 6, $8,10,12$, dan seterusnya sehingga mencapai jumlah 127 responden.

Analisis data yang dilakukan dalam penelitian ini dilakukan dengan menggunakan etode analisis deskriptif untuk menggambarkan gejala secara apa adanya (Bungin, 2011: 181). Dalam penelitian ini analisis deskriptif digunakan untuk menggambarkan konsep diri anggota AIESEC LC Bandung dan keefektifan komunikasi antarpribadi yang dilakukan dengan data berupa umur dan jenis kelamin responden.

Selanjutnya metode analisis statistik inferensial. Menurut Bungin (2011: 172) analisis

Tabel 1 Operasionalisasi Variabel

\begin{tabular}{|c|c|c|}
\hline Variabel & Sub Variabel (Dimensi) & Indikator \\
\hline \multirow{7}{*}{$\begin{array}{c}\mathrm{X} \\
\text { Konsep Diri }\end{array}$} & \multirow{3}{*}{ Pengetahuan mengenai diri sendiri } & Faktor dasar \\
\hline & & Julukan \\
\hline & & Kualitas pembanding \\
\hline & \multirow{2}{*}{ Harapan mengenai diri sendiri } & Cita-cita \\
\hline & & Diri ideal \\
\hline & \multirow{2}{*}{ Penilaian mengenai diri sendiri } & Evaluasi \\
\hline & & Harga diri \\
\hline Variabel & Sub Variabel (Dimensi) & Indikator \\
\hline \multirow{11}{*}{$\begin{array}{c}\text { Y } \\
\text { Keefektifan } \\
\text { Komunikasi } \\
\text { Antarpribadi }\end{array}$} & \multirow{3}{*}{ Keterbukaan } & Kesediaan memberi informasi \\
\hline & & Kejujuran \\
\hline & & Kepemilikan perasaan dan pikiran \\
\hline & \multirow{2}{*}{ Empati } & Mengetahui perasaan orang lain \\
\hline & & Merasakan perasaan orang lain \\
\hline & \multirow{3}{*}{ Sikap mendukung } & Spontan \\
\hline & & Deskriptif \\
\hline & & Provisional \\
\hline & Sikap positif & Memberikan dorongan \\
\hline & \multirow{2}{*}{ Kesetaraan } & Pengakuan setara \\
\hline & & Menyumbangkan hal penting \\
\hline
\end{tabular}


statistik untuk jenis penelitian eksplanasi yang bertujuan melihat hubungan kausalitas diantara gejala-gejala adalah dengan menggunakan statistik inferensial. Uuntuk tujuan analisis data dan pengujian hipotesis, digunakan taraf signifikansi sebesar $\alpha=5$ sehingga tingkat kepercayaanya 95\%. Karena sampel dalam penelitian ini termasuk kategori sampel besar dengan $\mathrm{n}>30$, yaitu 127 sampel, maka peneliti menggunakan analisis korelasi Spearman $\left(r_{s}\right)$ untuk mengetahui arah hubungan dan kekuatan hubungan dan uji z untuk mengetahui, diterima atau tidaknya hubungan antara variabel tersebut atau pengujian hipotesis.

Dengan catatan nilai dari koefisien korelasi $\left(r_{s}\right)$ yang diterima berkisar antara- 1 dan +1 atau $-1<\mathrm{r}<+1$ (Siregar, 2013: 251). Jika $Z_{\text {hitung }}>$ $\mathrm{Z}_{\text {tabel }}$ atau $-\mathrm{Z}_{\text {hitung }}<-\mathrm{Z}_{\text {tabel }}$ maka $\mathrm{H}_{0}$ ditolak dan $\mathrm{H}_{1}$ diterima. Jika $-\mathrm{Z}_{\text {tabel }}<\mathrm{Z}_{\text {hitung }}<\mathrm{Z}_{\text {tabel }}$ maka $\mathrm{H}_{0}$ diterima dan $\mathrm{H}_{1}$ ditolak

\section{HASIL DAN PEMBAHASAN}

Sebelum angket disebar kepada 127 responden, dilakukan uji validitas dan reliabilitas terlebih dahulu kepada 30 responden. Hasil uji validitas yang dilakukan terhadap alat ukur penelitian pada dimensi Konsep Diri (Variabel $\mathrm{X})$ menunjukkan bahwa dari 21 item/pernyataan terdapat 1 item yang tidak valid sedangkan 20 item lainnya dinyatakan valid. Hasil uji validitas terhadap dimensi Keefektifan Komunikasi Antarpribadi (Variabel Y), sebanyak 26 item/ pernyataan, seluruhnya dinyatakan valid. Hasil uji reliabilitas terhadap 20 item/pernyataan pada variabel konsep diri dan 26 item/pernyataan pada variabel keefektifan komunikasi antarpribadi dapat dinyatakan reliabel atau dapat diandalkan).

Berdasarkan hasil perhitungan hubungan antardimensi pada variabel diperoleh 2 koefisien korelasi pada tingkat kuat, searah, dan signifikan; 12 koefisien korelasi pada tingkat cukup, searah, dan signifikan; dan 1 koefisien korelasi pada tingkat lemat, tetapi searah dan signifikan.

Adapun hubungan antardimensi pada variabel $\mathrm{X}$ dengan variabel $\mathrm{Y}$ menunjukkan: hubungan antara dimensi pengetahuan mengenai diri sendiri (X1) dengan variabel keefektifan komunikasi antarpribadi (Y) adalah sebesar 0,637. Menurut interpretasi koefisien korelasi, nilai koefisien korelasi antara dimensi
$\mathrm{X} 1$ dengan variabel $\mathrm{Y}$ tersebut termasuk ke dalam tingkat hubungan kuat. Artinya terdapat hubungan yang erat diantara pengetahuan mengenai diri sendiri yang dimiliki anggota AIESEC LC Bandung dengan keefektifan komunikasi antarpribadi. Nilai korelasi yang diperoleh positif menunjukkan hubungan searah diantara keduanya, sehingga semakin tinggi pengetahuan mengenai diri sendiri yang dimiliki anggota AIESEC LC Bandung, semakin tinggi kefeektifan komunikasi antarpribadi yang dilakukan. Hasil pengujian dengan statistik $\mathrm{Z}$ diperoleh nilai $Z_{\text {hitung }}(7,13)>Z_{\text {tabel }}(1,96)$. Hal tersebut menunjukkan penolakan $\mathrm{H}_{0}$ atau dengan kata lain terdapat hubungan signifikan antara dimensi pengetahuan mengenai diri sendiri (X1) dengan variabel keefektifan komunikasi antarpribadi (Y).

Jalaluddin Rakhmat yang mengatakan bahwa pengetahuan tentang diri akan meningkatkan komunikasi dan pada saat yang sama, berkomunikasi dengan orang lain meningkatkan pengetahuan tentang diri. Dengan membuka diri, konsep diri menjadi lebih dekat pada kenyataan. Bila konsep diri sesuai dengan pengalaman, orang akan lebih terbuka untuk menerima pengalaman-pengalaman dan gagasan-gagasan baru, cenderung menghindari sikap defensif, dan lebih cermat memandang dirinya dan orang lain (Rakhmat, 2011: 105). Maka, pengetahuan mengenai diri sendiri yang dimiliki anggota AIESEC LC Bandung akan meningkatkan komunikasi yang mereka lakukan dan pada saat yang sama, berkomunikasi dengan orang lain meningkatkan pengetahuan anggota AIESEC LC Bandung mengenai dirinya sendiri. Dengan membuka diri, konsep diri anggota AIESEC LC Bandung menjadi lebih dekat pada kenyataan. Konsep diri anggota AIESEC LC Bandung yang sesuai dengan pengalaman akan membuat anggota AIESEC LC Bandung lebih terbuka untuk menerima pengalaman dan gagasan baru, cenderung menghindari sikap defensif, dan lebih cermat memandang dirinya sendiri maupun orang lain.

Hubungan antara dimensi harapan mengenai diri sendiri (X2) dengan variabel keefektifan komunikasi antarpribadi (Y) adalah sebesar 0,712. Menurut interpretasi koefisien korelasi, nilai koefisien korelasi antara dimensi $\mathrm{X} 2$ dengan variabel Y termasuk ke dalam tingkat hubungan kuat. Artinya terdapat hubungan yang erat diantara harapan mengenai diri sendiri yang 
dimiliki anggota AIESEC LC Bandung dengan keefektifan komunikasi antarpribadi. Nilai korelasi yang diperoleh positif menunjukkan hubungan searah diantara keduanya, sehingga semakin tinggi harapan mengenai diri sendiri yang dimiliki anggota AIESEC LC Bandung, semakin tinggi kefeektifan komunikasi antarpribadi yang dilakukan. Hasil pengujian dengan statistik $Z$ diperoleh nilai $Z_{\text {hitung }}(7,992)$ $>Z_{\text {tabel }}(1,96)$. Hal tersebut menunjukkan penolakan $\mathrm{H}_{0}$ atau dengan kata lain terdapat hubungan yang signifikan antara dimensi harapan mengenai diri sendiri (X2) dengan variabel keefektifan komunikasi antarpribadi (Y).

Secara psikologis, individu yang memiliki harapan tinggi pada dirinya, mau membuka diri kepada orang lain, sehingga orang lain yang diajak bicara akan merasa aman dalam melakukan komunikasi antarpribadi yang akhirnya orang lain tersebut akan turut membuka diri. Sebaliknya, keinginan untuk menutup diri, selain karena konsep diri yang negatif timbul dari kurangnya kepercayaan kepada kemampuan diri sendiri. Orang yang tidak menyenangi dirinya merasa bahwa dirinya tidak akan mampu mengatasi persoalan. Orang yang kurang percaya diri cenderung menghidari situasi komunikasi. Takut diejek atau disalahkan orang lain. Dalam diskusi, akan lebih banyak diam. Dalam pidato, akan berbicara terpatahpatah.

Ketakutan untuk melakukan komunikasi dikenal sebagai communication apprehension. Orang yang aprehensif dalam berkomunikasi, akan menarik diri dari pergaulan, berusaha sekecil mungkin berkomunikasi, dan hanya akan berkomunikasi apabila terdesak saja. Mereka cenderung dianggap tidak menarik bagi orang lain, kurang kredibel, dan sangat jarang menduduki jabatan pemimpin. Tidak semua aprehensi komunikasi disebabkan kurangnya rasa percaya diri, tetapi percaya diri adalah faktor yang paling menentukan. Maxwell Maltz mengatakan, "Believe in your self and you will succeed". Jadi untuk meraih sukses, perlu ditingkatkan kepercayaan diri dengan menimbulkan konsep diri sehat (Rakhmat, 2011: 107).

Anggota AIESEC LC Bandung bukan termasuk individu yang memiliki aprehensi dalam berkomunikasi. Dapat dikatakan bahwa anggota AIESEC LC Bandung mau membuka diri kepada orang lain, sehingga orang lain yang diajak bicara merasa aman dalam melakukan komunikasi antarpribadi dengan mereka yang akhirnya orang lain tersebut turut membuka diri. Selain itu, anggota AIESEC LC Bandung tidak dapat digolongkan sebagai orang yang kurang percaya diri atau menghindari situasi komunikasi.

Hubungan antara dimensipenilaian mengenai diri sendiri (X3) dengan variabel keefektifan komunikasi antarpribadi (Y) adalah sebesar 0,724. Menurut interpretasi koefisien korelasi, nilai koefisien korelasi antara dimensi X3 dengan variabel $\mathrm{Y}$ termasuk ke dalam tingkat hubungan kuat. Artinya terdapat hubungan yang erat diantara penilaian mengenai diri sendiri yang dimiliki anggota AIESEC LC Bandung dengan keefektifan komunikasi antarpribadi. Nilai korelasi yang diperoleh positif menunjukkan hubungan searah diantara keduanya, sehingga semakin baik penilaian mengenai diri sendiri yang dimiliki anggota AIESEC LC Bandung, semakin tinggi kefeektifan komunikasi antarpribadi yang dilakukan. Hasil pengujian dengan statistik $Z$ diperoleh nilai $Z_{\text {hitung }}(8,127)>Z_{\text {tabel }}(1,96)$. $\mathrm{Hal}$ tersebut menunjukkan penolakan $\mathrm{H}_{0}$ atau dengan kata lain terdapat hubungan signifikan antara dimensi penilaian mengenai diri sendiri (X3) dengan variabel keefektifan komunikasi antarpribadi (Y).

Hal tersebut dikarenakan anggota AIESEC LC Bandung yang menilai dirinya secara positif akan memiliki sikap terbuka yang sangat besar pengaruhnya dalam menimbulkan komunikasi antarpribadi yang efektif. Perkembangan konsep diri merupakan proses yang berlanjut di sepanjang kehidupan manusia. Dengan bertambahnya umur, pandangan tentang diri ini menjadi lebih banyak didasari oleh nilai-nilai yang diperoleh dari interaksi dengan orang lain.

\section{SIMPULAN}

Kesimpulan penelitian ini adalah hubungan antara variabel konsep diri $(\mathrm{X})$ dengan variabel keefektifan komunikasi antarpribadi (Y) adalah sebesar 0,839. Nilai koefisien korelasi antara kedua variabel tersebut termasuk ke dalam tingkat hubungan sangat kuat. Artinya terdapat hubungan yang sangat erat diantara konsep diri anggota AIESEC LC Bandung dengan keefektifan komunikasi antarpribadi. Nilai 
korelasi yang diperoleh positif menunjukkan hubungan searah diantara keduanya, sehingga semakin baik konsep diri sendiri yang dimiliki anggota AIESEC LC Bandung, semakin tinggi kefeektifan komunikasi antarpribadi yang dilakukan. Hasil pengujian dengan statistik $\mathrm{Z}$ diperoleh nilai $Z_{\text {hitung }}(9,418)>Z_{\text {tabel }}(1,96)$. Hal tersebut menunjukkan penolakan $\mathrm{H}_{0}$ atau dengan kata lain terdapat hubungan yang signifikan antara variabel konsep diri (X) dengan variabel keefektifan komunikasi antarpribadi (Y).

Penelitian didasari oleh pernyataan bahwa konsep diri merupakan faktor yang sangat menentukan dalam komunikasi antarpribadi, hal tersebut dibuktikan dengan nilai koefisien korelasi diantara keduanya yang termasuk ke dalam tingkat hubungan sangat kuat. Tetapi jika dilihat dari nilai koefisien korelasi antardimensi, sebagian besar menunjukkan hubungan yang cukup erat. Maka saran teoritis dari peneliti, perlu dikembangkan penelitian lebih lanjut untuk mengetahui variabel lain yang menentukan keefektifan komunikasi antarpribadi, selain konsep diri.

Saran praktis yang diajukan oleh peneliti mengacu kepada hubungan antara pengetahuan mengenai diri sendiri dengan kesetaraan pada saat berkomunikasi yang termasuk ke dalam tingkat hubungan lemah. Sebagai organisasi pemuda terbesar di dunia, yang bertujuan untuk mengembangkan kepemimpinan di kalangan pemuda, AIESEC memiliki sistem yang disebut AIESEC Experience (AIESEC XP).Hal ini bisa saja menjadi penyebab lemahnya hubungan antara pengetahuan mengenai diri sendiri yang dimiliki anggota AIESEC dengan kesetaraan dalam komunikasi antarpribadi. Karena anggota AIESEC yang memiliki pengetahuan bahwa dirinya belum mengikuti semua tahapan
AIESEC XP secara maksimal, merasa tidak setara pada saat melakukan komunikasi antarpribadi dengan anggota AIESEC lain yang sudah mengikuti semua tahap AIESEC XP. Sehingga peneliti memberikan saran agar AIESEC tidak terlalu membedakan anggotanya berdasarkan tahapan pada AIESEC XP, dengan mengadakan kegiatan yang melibatkan anggota dari semua tahapan AIESEC XP.

\section{DAFTAR PUSTAKA}

Bungin, B. (2011). Metodologi penelitian kuantitatif: komunikasi, ekonomi, dan kebijakan publik, serta ilmu-ilmu sosial lainnya. Edisi Kedua. Jakarta: Prenada Media Group.

Calhoun, J. F. \& Acocella, J. R.(1995). Psikologi tentang penyesuaian dan hubungan kemanusiaan. Semarang: IKIP Semarang Press.

Creswell, J.W. (2012). Research design. Terjemahan Achmad Fawaid. Yogyakarta: Pustaka Pelajar.

DeVito, J. A. (2011). Komunikasi antarmanusia. Edisi Kelima. Jakarta: Karisma Publishing Group.

Lane, S. D. (2008). Interpersonal communication: competence and contexts. Boston: Pearson Education.

Rakhmat, J. (2011). Psikologi komunikasi. Bandung: Remaja Rosdakarya.

Siregar, S. (2013). Metode penelitian kuantitatif dilengkapi perbandingan perhitungan Manual \& SPSS. Jakarta: Kencana Prenada Media Group.

Database AIESEC LC Bandung. 2014. 